\section{N.R. Robles ${ }^{\mathrm{a}}$ \\ J.M. Escola a \\ L. Albarran ${ }^{\mathrm{b}}$ \\ R. Espada}

Sección de Nefrología,

a Servicio de Análisis Clínicos, Hospital

Infanta Cristina, and

b Clinica Phermodiálisis, Badajoz, Spain

\title{
Correlation of Serum Magnesium and Serum Lipid Levels in Hemodialysis Patients
}

All patients had venous blood taken after a 12-hour fast. The serum was separated and stored at $4{ }^{\circ} \mathrm{C}$ for analysis of total cholesterol, triglycerides, total HDL-C and HDL triglycerides (HDL-TG), HDL-C fractions $\left(\mathrm{HDL}_{2}-\mathrm{C}, \mathrm{HDL}_{3}-\mathrm{C}\right)$, low-density-lipoprotein (LDL) cholesterol (LDL-C) and triglycerides (LDL-TG), very-LDL (VLDL) cholesterol (VLDL-C) and triglycerides (VLDL-TG), apolipoprotein A (Apo A) and apolipoprotein $B_{100}$ (Apo B). All results are expressed as means with 1 standard deviation. Lipid values were compared by the unpaired Student $t$ test. The relationship between magnesium and lipids was studied using univariate regression analysis.

Serum lipid levels in the three groups are compared in table 2 . No differences were found between the three groups for HDL-C, $\mathrm{HDL}_{2}-\mathrm{C}$ and $\mathrm{HDL}_{3}-\mathrm{C}$. The $\mathrm{A}$ and $\mathrm{B}$ groups had similar VLDL-C levels, which were lower than those of group $C(p<0.01)$. LDL-C was lower in group B than in $C(p<0.001)$, and was lowest in $A(p<0.001)$. There was a progressive increase of triglyceride levels from the $\mathrm{A}$ to the $\mathrm{C}$ group but it was not significant. The three groups had similar Apo-A levels. Apo-B levels were highest in $\mathrm{C}$, lower in $B(p<0.001)$ and lowest in $A(p<0.001)$. A significant increase in LDL-TG was found $(p<0.05)$. No differences were found in calcium, phosphorus and parathyroid hormone. Magnesium was higher in group B than in A, but this difference was not significant. Group $\mathrm{C}$ had the highest magnesium levels $(\mathrm{p}<0.05$ relative to groups $\mathrm{A}$ and $\mathrm{B})$.

The linear correlation of total cholesterol versus magnesium was significant $(\mathrm{r}=0.55$, $\mathrm{p}<0.001)$. The linear regression was statistically significant for magnesium versus LDL-
$\mathrm{C}(\mathrm{r}=0.52, \mathrm{p}<0.01)$. A significant correlation was found between VLDL-C and magnesium $(r=0.49, p<0.01)$, as well as a positive correlation between Apo B and magne$\operatorname{sium}(r=0.52, p<0.01)$.

It has been suggested that magnesium deficiency is related to alterations in lipid metabolism. In monkeys, magnesium deprivation associated with an atherogenic diet leads to high blood cholesterol levels [8]. Magnesium-deficient rats maintained on a high-carbohydrate diet had high blood triglyceride levels [6]; thus in magnesium-deficient non-uremic rats no changes in serum total cholesterol were found. Recently Inagaki et al. [7] found that in uremic rats magnesium deficiency increased serum triglyceride levels and decreased HDL-C levels.

Surprisingly, in the present results, a positive significant correlation between magnesium levels and total cholesterol, LDL-C, VLDL-C and apo-B levels was found in hemodialyzed uremic patients. There was also a nearly significant correlation of triglycerides and magnesium levels. At first sight our data seem to contradict accumulated experience, but there are conflicting data on cholesterol in man and the experimental rat. Whereas in uremic patients HDL-C is commonly reduced, in contrast, in uremic rats elevated total cholesterol and HDL-C levels have been observed [7]. Moreover, while most cholesterol appears to be transported in HDL in rats; in man, LDL appears to be the principal class involved in the transport of plasma cholesterol [9]. Experimentally, magnesium seems not to increase lipoprotein synthesis but to be involved in the regulation of cholesterol ester hydrolases, which promote the mobilization of these esters [10,

\begin{tabular}{|c|c|c|}
\hline KARGER & $\begin{array}{l}\text { (c) } 1998 \text { S. Karger AG, Basel } \\
0028-2766 / 98 / 0781-0118 \$ 15.00 / 0\end{array}$ & $\begin{array}{l}\text { Dr. N.R. Robles Pérez } \\
\text { Apdo. } 20054\end{array}$ \\
\hline $\begin{array}{l}\text { Fax + } 41613061234 \\
\text { E-Mail karger@karger.ch } \\
\text { www. karger.com }\end{array}$ & $\begin{array}{l}\text { This article is also accessible online at: } \\
\mathrm{http}: / / \text { BioMedNet.com/karger }\end{array}$ & E-06080 Badajoz (Spain) \\
\hline
\end{tabular}


Table 1. Biochemical status of uremic patients

\begin{tabular}{lccc}
\hline & Group A & Group B & Group C \\
\hline Glucose & $104.8 \pm 30.5$ & $110.4 \pm 47.5$ & $94.5 \pm 14.6$ \\
Urea & $185.5 \pm 39.2$ & $189.3 \pm 29.0$ & $181.2 \pm 30.2$ \\
Creatinine & $10.0 \pm 3.7$ & $11.5 \pm 2.5$ & $12.4 \pm 1.6$ \\
Uric acid & $7.6 \pm 1.2$ & $7.7 \pm 1.4$ & $6.8 \pm 1.4$ \\
Albumin & $4.8 \pm 0.8$ & $4.8 \pm 0.9$ & $4.3 \pm 0.9$ \\
Total protein & $6.9 \pm 0.8$ & $6.9 \pm 0.3$ & $7.0 \pm 0.4$ \\
TAC & $62.1 \pm 13.1$ & $58.8 \pm 11.1$ & $58.1 \pm 8.1$ \\
Kt/V & $1.02 \pm 0.11$ & $0.96 \pm 0.13$ & $1.05 \pm 0.14$ \\
PCR & $1.00 \pm 0.23$ & $0.97 \pm 0.15$ & $1.05 \pm 0.15$ \\
Calcium, mg/dl & $9.0 \pm 1.2$ & $9.3 \pm 0.9$ & $9.2 \pm 0.8$ \\
Phosphorus, mg/dl & $5.0 \pm 2.3$ & $5.8 \pm 1.6$ & $5.9 \pm 2.5$ \\
Magnesium, mg/dl & $2.0 \pm 0.3$ & $2.1 \pm 0.2$ & $2.4 \pm 0.3 *$ \\
PTH, pg/ml & $378.8 \pm 465.5$ & $162.5 \pm 136.5$ & $223.4 \pm 300.8$
\end{tabular}

$* \mathrm{p}<0.05$ compared to groups $\mathrm{A}$ and $\mathrm{B} . \mathrm{TAC}=$ Time-averaged concentration of urea; $\mathrm{Kt} / \mathrm{V}=$ whole-body urea clearance; $\mathrm{PCR}=$ protein catabolic rate; $\mathrm{PTH}=$ parathyroid hormone.
Table 2. Lipid and lipoprotein levels of study subjects

\begin{tabular}{lccc}
\hline & Group A & Group B & Group C \\
\hline Cholesterol & $176.6 \pm 19.3$ & $215.8 \pm 11.7^{1}$ & $289.9 \pm 49.4^{1,2}$ \\
HDL-C & $33.3 \pm 12.4$ & $38.1 \pm 15.8$ & $40.8 \pm 34.3$ \\
LDL-C & $104.3 \pm 26.5$ & $141.8 \pm 23.1^{3}$ & $196.2 \pm 30.6^{1,4}$ \\
VLDL-C & $39.1 \pm 15.3$ & $35.9 \pm 9.8$ & $61.8 \pm 31.7^{5}$ \\
HDL $-C$ & $8.8 \pm 4.8$ & $11.4 \pm 6.5$ & $7.9 \pm 4.2$ \\
HDL $-C$ & $24.5 \pm 7.9$ & $26.7 \pm 10.0$ & $21.8 \pm 9.1$ \\
Triglycerides & $114.1 \pm 48.8$ & $177.4 \pm 74.6^{6}$ & $225.4 \pm 151.2^{6}$ \\
HDL-TG & $12.7 \pm 5.1$ & $19.5 \pm 9.6$ & $13.3 \pm 5.1$ \\
LDL-TG & $56.7 \pm 17.8$ & $75.8 \pm 27.4$ & $92.3 \pm 37.6$ \\
VLDL-TG & $47.7 \pm 33.0$ & $82.2 \pm 49.9$ & $119.8 \pm 114.9^{7}$ \\
Apo A & $126.6 \pm 12.8$ & $131.6 \pm 16.5$ & $122.9 \pm 13.0$ \\
Apo B & $108.0 \pm 14.5$ & $128.8 \pm 12.6^{3}$ & $159.5 \pm 16.9^{1,4}$ \\
\hline
\end{tabular}

All values expressed as $\mathrm{mg} / \mathrm{dl}$.

$1 \mathrm{p}<0.001$ compared to group A.

$2 \mathrm{p}<0.01$ compared to group B.

$3 \mathrm{p}<0.01$ compared to group A.

$4 \mathrm{p}<0.001$ compared to group $\mathrm{B}$.

$\mathrm{p}<0.05$ compared to group B.

$\mathrm{p}<0.1$ compared to group $\mathrm{A}$.

$\mathrm{p}<0.05$ compared to group A.
11]. Therefore, if magnesium can induce an increase in HDL-C in rats, it could be expected to induce an increase in LDL-C in man, as our results showed.

Magnesium seems to have little effect on triglycerides. Uremic magnesium-deficient rats have higher triglyceride levels than uremic non-magnesium-deficient controls [7]. In our data there was a trend of increasing triglyceride levels with increasing magnesium levels. It is known that magnesium may induce changes in hepatic triglyceride metabolism [6].

Hyperparathyroidism is related to disturbances of lipid metabolism [12]. Furthermore, parathormone secretion is influenced by magnesium [13]. In the present results there were no notable differences in calcium, phosphorus or parathyroid hormone levels between the three groups. We can therefore eliminate the influence of parathyroid hormone in our results. Lipid levels seems not to be influenced by $1,25-(\mathrm{OH})_{2}-\mathrm{D}_{3}$ treatment in uremic hemodialysis patients [14].

In conclusion, the results suggest that magnesium might affect lipid metabolism in hemodialysis patients. The increase of serum magnesium levels in hemodialysis patients may worsen dyslipemia. Further clinical studies are required to confirm this hypothesis.

Correlation of Serum Magnesium and Serum Lipid Levels in Hemodialysis Patients

\section{References}

1 Lidner A, Charra B, Sherrard D, Scribner BM: Accelerated atherosclerosis in prolonged maintenance hemodialysis. N Engl J Med 1974;290: 697-701.

2 Ma KW, Greene EL, Raij L: Cardiovascular risk factors in chronic renal failure and hemodialysis populations. Am J Kidney Dis 1992; 19:505-513.

3 Appel G: Lipid abnormalities in renal disease. Kidney Int 1991;39:169-183.

4 Aesbischer N, Aesbischer P, Fellary G, et al: Factors influencing the hypermagnesemia of chronic renal failure. Proc Eur Dial Transplant Assoc 1985;22:97-100.

5 Bersohn I, Oelofse PJ: Correlation of serummagnesium and serum-cholesterol levels in South African Bantu and European subjects. Lancet 1957;i:1020-1021.

6 Rayssiguier Y, Gueux E, Weiser D: Effects of magnesium deficiency on lipid metabolism in rats fed a high carbohydrate diet. J Nutr 1981; 111:1877-1883

7 Inagaki O, Shono T, Nakagawa K, Gomikawa S, Mori H, Fujita Y: Effects of magnesium deficiency on lipid metabolism in uremic rats. Nephron 1990;55:176-180.
8 Vitale JJ, Velez H, Guzman C, et al: Magnesium deficiency in the cebus monkey. Circ Res 1963;12:642-650.

9 Bagdade JD, Yee E, Wilson DE, et al: Hyperlipidemia in renal failure: Studies of plasma lipoprotein, hepatic triglyceride production, and tissue lipoprotein lipase in a chronically uremic rat model. J Lab Clin Med 1978;91: 176-186.

10 Hernandez ML, Martinez MJ, Chico Y, Fernandez de Marticorena I, Lacort M, Ochoa B: Divalent metal ions as modulators of rat liver microsomal cholesterol esterase. Rev Esp Fisiol 1993;49:107-114.

11 Martinez MJ, Hernandez ML, Lacort M, Ochoa B: Regulation of rat liver microsomal cholesterol ester hydrolase by reversible phosphorylation. Lipids 1994;29:7-13.

12 Shoji T, Nishizawa Y, Nishitani H, Yamakawa M, Morii H: Impaired metabolism of high density lipoprotein in uremic patients. Kidney Int 1992;41:1653-1651.

13 Massry SG, Coburn JW, Kleeman CR: Evidence for suppression of parathyroid gland activity by hypermagnesemia. J Clin Invest 1970; 49:1619-1629.

14 Yeksan M, Turk S, Polat M, Cigli A, Erdogan Y: Effects of $1,25(\mathrm{OH})_{2} \mathrm{D}_{3}$ treatment on lipid levels in uremic hemodialysis patients. Int $\mathbf{J}$ Artif Org 1992;15:704-707. 